The 16th Economic International Conference

New Challenges and Opportunities for the Economy 4.0,

May 7-8th, 2020, Suceava, Romania

\title{
The Evolution of the Limitation of the Application of the Accounts Function by Romanian Companies
}

Claudia-Elena GRIGORAS-ICHIM, Lucia MOROSAN-DANILA https://doi.org/10.18662/lumproc/ncoe4.0.2020/13

How to cite: Grigoras-Ichim, C.-E., \& Morosan-Danila, L. (2020). The Evolution of the Limitation of the Application of the Accounts Function by Romanian Companies. In C. Nastase (vol. ed.), Lumen Proceedings: Vol. 13. 16th Economic International Conference NCOE 4.02020 (pp. 139-147). Iasi, Romania: LUMEN Publishing House.

https://doi.org/10.18662/lumproc/ncoe4.0.2020/13 


\title{
The Evolution of the Limitation of the Application of the Accounts Function by Romanian Companies
}

\author{
Claudia-Elena GRIGORAS-ICHIM ${ }^{1}$, Lucia MOROSAN-DANILA²
}

Abstract

With Romania's accession to the European Union and adaptation to international accounting standards, national accounting and tax legislation has seen various changes and adjustments for active companies, both nationally and internationally. Economic reality has imposed an accelerated pace on companies over time and is constantly adapting to meet the demands of the internal or external market, and the accounting and taxation is an important constant to all stakebolders. Access to international stock exchanges and investments stimulates the governance to amend and develop the legislation in force, clearly if it is not always to the advantage of Romanian companies. In this sense, the permanent changes have forced companies to invest and spend larger amounts on the infrastructure needed for management and financial accounting or, as an alternative, for outsourced financial-accounting consulting services. This article presents the evolution over time of legislative changes in Romania regarding the obligation of private companies to comply with accounting regulations and, in particular, those related to the use of the chart of accounts in accounting records.

Keywords: Accounting legislation; accounts; accounting; taxation.

\footnotetext{
1 "Stefan cel Mare" University of Suceava, Romania, claudia.grigoras@,usm.ro

2 "Stefan cel Mare" University of Suceava, Romania, lucia.danila@usm.ro. 


\section{Introduction}

In economic and financial communication, the common language is represented by accounting rules that allow the process of converting operations related to economic evolution into figures (the situation of the one who prepares the interim financial reports) and a process of reconversion of figures into economic operations (the situation of the one who uses the reports interim financial). That is why the necessary "accounting standardization process" takes place, which involves a set of rules capable of standardizing the criteria based on the representation and interpretation of values in the interim financial reports. These norms, either general or specific, may derive from accounting practice or may be established by legislative provisions [5].

In the first case we speak of the "normalization of accounting practices" specific to the Anglo-Saxon countries: it lacks reference normative systems, being influenced by operational practice. The accounting rules that define the procedures of economic highlighting and evaluation derive from the best practices fully recognized by professional accountants, which are codified by the professional bodies, respecting the best economic-financial doctrine.

In the second case we speak of "regulated / legislative accounting normalization" - characteristic of our country, where the legislator has the duty to develop general accounting rules to define the minimum aspects of economic and financial communication. The drafting of interim financial reports is presented through a set of rules and refers only to the "normalization" of the schemes and structures of interim financial reports or the values presented in the financial reports.

This entails a reduced flexibility of such an accounting regulatory system, which avoids the possibility of undergoing rapid changes that may arise from the need to solve new accounting problems, calling into question the assignment of the regulatory role in accounting of the legislator. Romanian. We consider that this is a rather technical, pragmatic and extremely complex matter (preparation and drafting of interim financial reports).

At present, regarding the national accounting, it is governed in Romania by the Accounting Law no. 82/1991 [12], republished, with subsequent amendments and completions, and the accounting norms are regulated by order of the Ministry of Public Finance, the care of approving the regulations to ensure the care must follow the observance of the economic agencies for the care of activities on the Romanian territory. 
The current Romanian accounting started with the achievement of the political independence in 1990, registering in these 20 years ups and downs, reaching at present the national standards and regulations adapted to the international ones.

\section{Problem Statement}

In the period 1993-1999, the control norms for the application of accounting laws and the encouragement of obligations for economic agents in Romania. In this sense, Regulation no. $704 / 1993$ to indicate the accounting laws no. 82/1991 introduce a new chart of accounts, maybe also methodological norms for the use of accounting accounts [24], which economic agencies are mandatory to comply with.

Romanian legislation have registered many and diverse changes, influencing directly and indirectly the activities of the companies. The specialized literature in Romania analysed in detail the evolution of accounting at national level, as well as the way of adapting to European and national standards, seen as an opportunity for companies to penetrate international markets [1], [2], [3],[7], [8], [9], [10],[11].

\section{Aims of the research}

Regarding the paper, it is aiming to analyse an evolution of a national scoring framework to see the use of the chart of accounts and a methodological norm for the use of a part, called functions for our accounts with Order 306/2002 [20]. The most important question of the moment is: are the companies using the chart of the accounts as proposed by the law?

\section{Research Methods}

This article combines basic (basic) research with usable research, with the aim of discovering new problems or developing new theoretical and practical approaches. The usefulness of such research lies in contributing to the future development of research, ensuring the necessary premises for future research. 


\section{Findings}

Starting with 1999, through Romanian accounting, through Order 403/1999 [21], the national regulations can be regulated with the Fourth Directive of a European Economic Community and with International Accounting Standards [6], being a step in the forefront in terms of financial financing. Both Order 403/1999, in accordance with Order 94/2001 [23], do not regulate and do not deal with the methodological norms of using a chart of accounts, but are specific Correspondence of the General Outline Plan with the format of annual accounts (Chapter 4 of the order).

Although the function of the accounts is not limiting, the national legislation in force obliges us to respect [19], in relation to the state institutions, the related special forms; for example, Order 79/2014 Preparation and submission of financial statements and annual accounting reports, provides:

"IV. Completion of the annual financial statements and of the simplified annual financial statements

A. The completion of the annual financial statements is performed using the General Chart of Accounts provided in Chapter IV of the Accounting Regulations compliant with the Fourth Directive of the European Economic Communities, component part of the Accounting Regulations compliant with the European directives, approved by the Order of the Minister of Public Finance no. 3055/2009, with subsequent amendments and completions." [22]

Corroborating the specified articles, it results that the economic agents are free to adapt the chart of accounts to their own needs, but at the same time to use exactly the forms provided by the Ministry of Public Finance.

Unfortunately, the legislation in Romania is constantly changing, through amendments, completions or repeals, and economic agents must continuously adapt to these changes. For example, Order no. 1802/2014 for the approval of the Accounting Regulations regarding the individual annual financial statements and the consolidated annual financial statements [18] underwent amendments brought by the following acts: Order $773 / 2015$; Order 1198/2015; Order 4160/2015; Order 1938/2016; Order 166/2017; Order 895/2017; Order 2827/2017; Order 470/2018; Order 1243/2018; Order 2531/2018; Order 3067/2018; Order 3456/2018; Order 2493/2019; Order $3781 / 2019$.

It is important to emphasize that companies listed on stock exchanges must prepare and submit half-yearly and annual financial statements according to Romanian legislation [17], as well as quarterly, half- 
yearly and annual financial statements according to international accounting standards (according to IAS 1 - Presentation of Financial Statements and IAS 34 - Interim Financial Reporting), as shown in Figure 2.

Figure 1. Evolution of the application of the account function

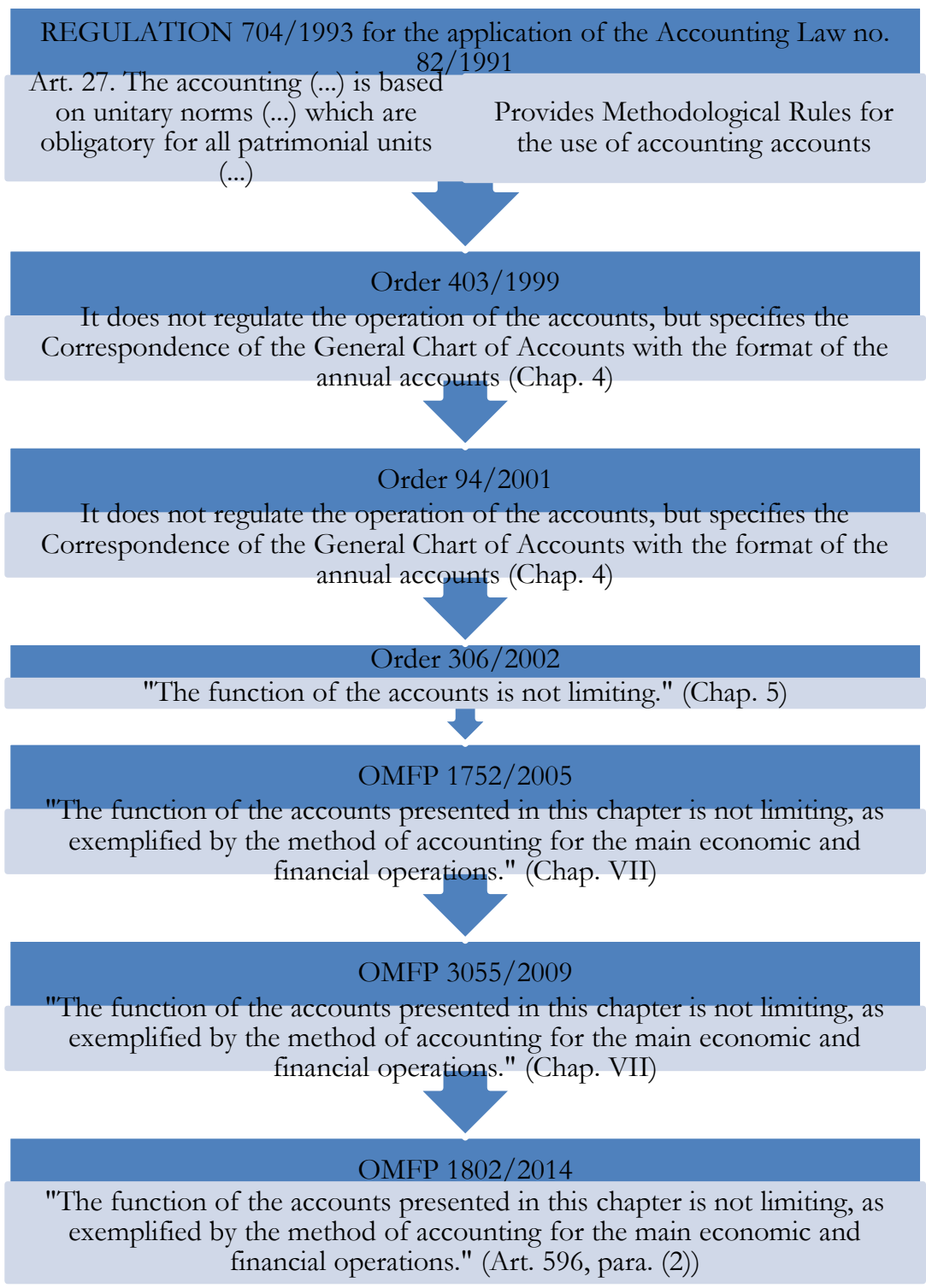

Professional accountants consider this double reporting an effort on their part, as the forms to be completed for this purpose are presented in 
different formats. The annual financial statements according to the orders of the Ministry of Public Finance are accessible only to persons who have studied accounting disciplines, because they are presented in the form of account symbols, grouped by categories of assets, equity and debt. In contrast, IAS / IFRS financial statements are more accessible to the general public due to the more flexible way of reporting [16], without reference to symbols of accounts.

Figure 2. Correspondence between national legislation and IAS 1 and IAS 34 on financial statements

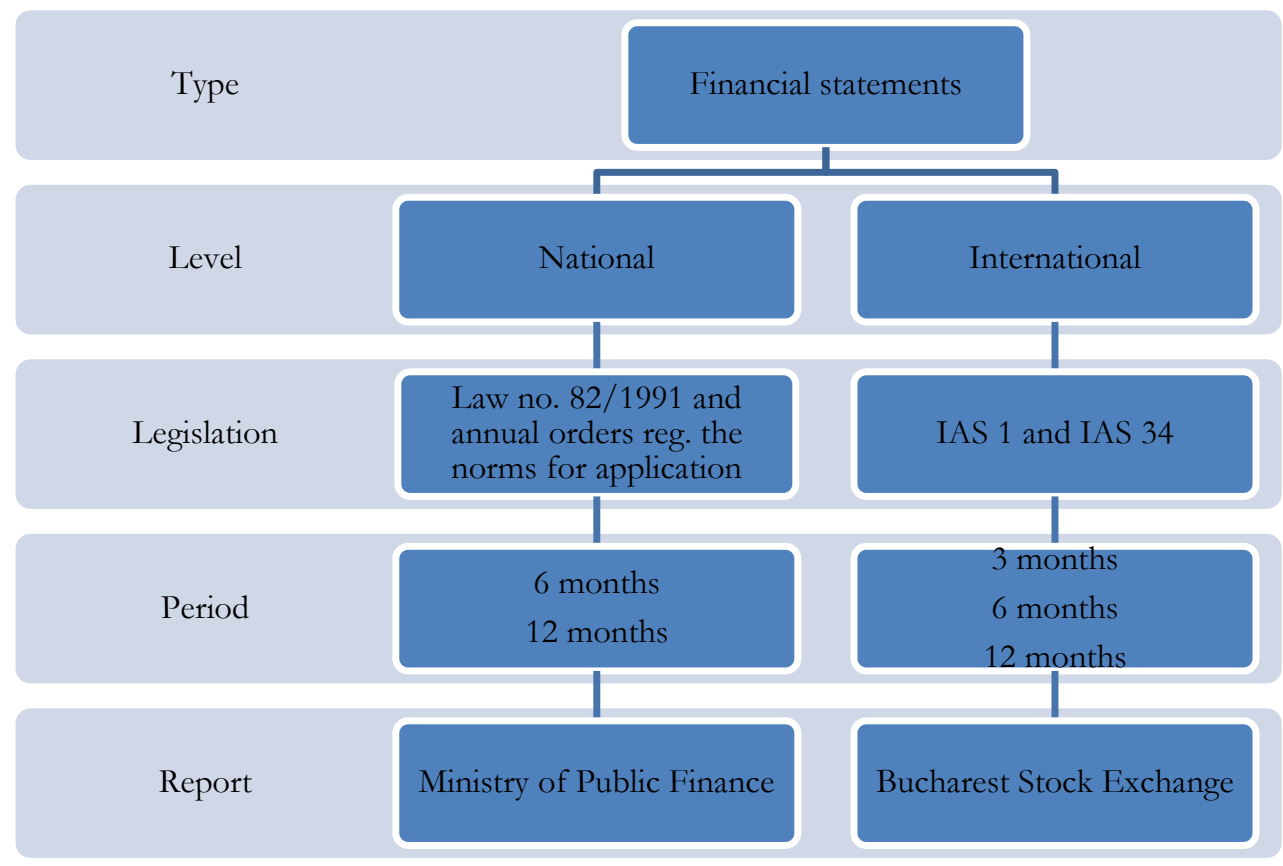

At present, the financial accounting is completely computerized [13], the economic agents being indirectly obliged to purchase specialized software, or to outsource this service, in order to be able to make the accounting records and the reports to the state institutions according to the legislation in force. In the current period, generated by COVID-19, the economic agents must be even more attentive to the legislative changes and to the terms of declaration and payment of the fiscal obligations, as well as the eventual fiscal facilities from which they can benefit. 


\section{Discussions}

The question that arises in the mind of the professional accountant remains: Are there or are there no limits in the applicability of accounting legislation, in general, and that of accounts, in particular?

The Romanian accounting system is complex, resulting from a vast legislative and normative system, consisting of laws, methodological norms, procedures, orders, etc., with accounting and fiscal implications in continuous modification or updating [15], as well as extremely interpretable [4]. Thus, it is up to the taxpayer to interpret and deal with this system.

In the future, it is recommended to develop research by conducting a detailed analysis on the application of accounting rules by Romanian companies, starting from the use of accounting rules starting from the records in financial accounting.

\section{Conclusions}

The freedom of economic agents to adapt their chart of accounts to their own needs is resulting from a simple expression presented by the law: „....in so far as national law permits their registration as elements of...” Romanian companies have the freedom and opportunity to know and apply accounting and tax legislation in their favour, so as to meet the needs of all stakeholders [14].

But in the same time, only through continuous study, assiduous practice and the open and cross-interpretation of legislation and norms beyond the limits of the act itself, denotes the true possibilities of the professional accountant to apply accounting laws.

\section{Acknowledgment}

This work is supported by project POCU 125040, entitled "Development of the tertiary university education to support the economic growth - PROGRESSIO", co-financed by the European Social Fund under the Human Capital Operational Program 2014-2020

\section{References}

[1] Albu N, Albu CN. International Financial Reporting Standards in an emerging economy: lessons from Romania. Australian accounting review, 22(4), 2012, 341-352. 
[2] Boghean F, Boghean C, Morosan-Danila L. Approaches and advances in the use of the financial-accounting information in the decision-making and innovative process, in 18th International Economic Conference: Crises after the crisis. Inquiries from a national, European and global perspective, Romania, 2011, pp. 34-40.

[3] Bunget OC, Dumitrescu AC, Farcane N, Caciuc L, Popa A. The impact of ias/ifrs on the romanian accounting rules; 2009.

[4] Ciubotariu M, Boghean F, Morosan-Danila L, Boghean C. Study on Tax Evasion Manifestation within Entities from Romania. ICEEM 2012: 2012 2ND INTERNATIONAL CONFERENCE ON ECONOMIC, EDUCATION AND MANAGEMENT, Vol. 1, 2012, pp. 365-371.

[5] Dumitrescu D. The Internal Audit, la Conferința Internațională Economia României post-aderare 2 ani în UE, ZEC, Reşița; 2008.

[6] Fourth Council Directive 78/660/EEC of 25 July 1978 based on Article 54 (3) (g) of the Treaty on the annual accounts of certain types of companies

[7] Grigoras-Ichim CE, Morosan-Danila L. Hierarchy of accounting information qualitative characteristics in financial reporting. The USV Annals of Economics and Public Administration, $16(1$ (23)), 2016, 183-191.

[8] Grigoraş-Ichim CE. Situation of Interim Financial Reporting in Romania. EcoForum, 6(1), 2017.

[9] Grigoraş-Ichim CE, Morosan-Danila L. The Importance of Financial Interim Reporting for the Position of Companies. The USV Annals of Economics and Public Administration. 2016; $15(2$ (22)): 182-187.

[10] Ionascu I, Ionascu M, Olimid L, Artemisa Calu D. An empirical evaluation of the costs of harmonizing Romanian accounting with international regulations (EU Directives and IAS/IFRS). Accounting in Europe. 2007; 4(2): 169-206.

[11] Istrate C. Impact of IFRS on Romanian accounting and tax rules for fixed tangibles assets. In Proceedings of the 7th International Conference Accounting and Management Information Systems, 2012, pp. 76-93.

[12] Law no. 82 of December 24, 1991 The Accounting Law

[13] Moroşan-Dănilă L. The stage of accounting computerization in Romania, Status and Prospects of Development of Accounting and Analytical Support of Entrepreneurship Management in the Conditions of European Integration Processes, Ukraine, 2015.

[14] Morosan-Danila L, Boghean F, Boghean C. Analysis of the Costs Role in Decision Making of the Companies from Suceava County, Romania. innovation and sustainable competitive advantage: from regional development to world economies. 2012, 1-5: 1541-1552.

[15] Morosan-Danila L, Grigoras-Ichim CE. Analysis of the Accounting Systems from Romania and Moldova. The USV Annals of Economics and Public Administration. 2015; 15(3):163-168.

[16] Nastase C, Morosan-Danila L. Taxation implications on entrepreneurship in Romania. Proceedings of the Conference "European Choice of Economic Development of the Region”, Ukraine, 2016, 94-95. 
[17] Ministry of Public Finance. Order no. 1752 of November 17, 2005 for the approval of the accounting regulations compliant with the European directives. Updated by 14 January 2008.

[18] Ministry of Public Finance. Order no. 1802 of December 29, 2014 for the approval of the Accounting Regulations regarding the individual annual financial statements and the consolidated annual financial statements. Published in: Official Gazette no. 963 of December 30, 2014.

[19] Ministry of Public Finance. Order no. 3055 of October 29, 2009 for the approval of the Accounting Regulations compliant with the European directives. Published in: Official Gazette no. 766 bis of November 10, 2009

[20] Ministry of Public Finance. Order no. 306 of February 26, 2002 for the approval of the simplified Accounting Regulations, harmonized with the European directives. Published in: Official Gazette no. 279 bis of April 25, 2002.

[21] Ministry of Public Finance. Order no. 403 of April 22, 1999 for the approval of the Accounting Regulations harmonized with the Fourth Directive of the European Economic Communities and with the International Accounting Standards. Published in the Official Gazette no. 480 of October 4, 1999.

[22] Ministry of Public Finance. Order no. 79/2014 on the main aspects related to the preparation and submission of annual financial statements and annual accounting reports of economic operators to the territorial units of the Ministry of Public Finance. Published in the Official Gazette, Part I no. 70 of January 29, 2014.

[23] Ministry of Public Finance. Order no. 94 of January 29, 2001 for the approval of the Accounting Regulations harmonized with the Fourth Directive of the European Economic Communities and with the International Accounting Standard. Published in: Official Gazette, Part I no. 85 of February 20, 2001.

[24] The Government of Romania. Regulation no. 704 of December 22, 1993 for the application of the Accounting Law no. 82/1991. Published in: Official Gazette no. 303 of December 22, 1993. 